African J. Biol. Sci., 16 (1): 53-62 (2020)

ISSN 1687-4870

e- ISSN 2314-5501 (online)

www.ajbs.journals.ekb.eg

E.mail: aasdjournal@yahoo.com

\title{
Comparison of some metabolic and sex hormones in selected vertebrates in different seasons
}

\author{
Esraa Ayad*, Naglaa El-orbany, Ayman Hydar and Kadry Elbakry \\ Zoology department, Faculty of Science, Damietta University New Damietta, Egypt \\ *esraaayad92@gmail.com
}

Received: Feb. 20, 2020; Accepted: Mar. 29, 2020; Available online : May 15, 2020

\section{ABSTRACT}

Different environmental factors affect animal physiological status. Day length and temperature are the two main factors that have been proved to cause changes in different hormones. The current study aimed to compare seasonal changes of some hormones such as testosterone $(\mathrm{T})$, estradiol-17- $\beta \quad\left(\mathrm{E}_{2}\right)$ and thyroid hormones ( $\mathrm{T}_{4}$, thyroxine; and $\mathrm{T}_{3}$, triiodothyronine) in selected vertebrates (amphibians, fish and mammals). These hormones were assayed by enzyme-linked immunosorbent assay (ELISA).

The present results indicated that; $\mathrm{T}_{3}$ had the highest concentration in both sexes of amphibians during winter and the lowest one was found in the investigated mammals of both sexes during summer and autumn. Regarding, $\mathrm{T}_{4}$ also showed the highest concentration in both sexes of amphibians during winter and the lowest one was recorded in male mammals during summer. In relation to $\mathrm{E}_{2}$, in females; the highest and detectable concentration was observed in fishes during summer and the lowest one was found in mammals during winter. On the other hand, in males, its highest concentration was found in birds during spring, and the lowest one was recorded in amphibians during winter. Testosterone showed the highest concentration in female birds during summer, while the lowest one was recorded in amphibians during summer. In males, the highest $\mathrm{T}$ level was observed in fishes during summer, while the lowest one was found in amphibians in the same season.

According to the results, significant changes in levels of steroid hormones, as well as thyroids in the selected animals from different classes were closely correlated to the length of the day and seasons.

Keywords: Seasonal changes, Steroid hormone, estradiol-17 $\beta$, Testosterone, Thyroid hormones, Thyroxine, Triiodothyronine.

\section{INTRODUCTION}

Different environmental factors

affect animal physiological status. Photoperiod (day length) and temperature are two main factors that have been proved to cause changes in different hormones during seasons. Photoperiodism is the ability of plants and animals to measure environmental day length (photoperiod), a process that underlies the so-called biological calendar (Nelson et al., 2010).
Photoperiodism defines the use of the annual cycle of day and night length to coordinate functions such as reproduction, fattening, hibernation, and migration with predictable changes in the environment, for example in food availability or climatic conditions.

Seasonal changes in physiology and behavior typically are innately timed longterm processes, requiring weeks or months to wax and wane. Therefore, additional to photoperiodic readout mechanisms, living 
Esraa Ayad et al.

creatures have evolved endogenous longterm timing devices, which allow them to anticipate forthcoming seasonal changes (Dardente et al., 2014).

It is well known that photoperiod affects the physiological behavior of animals by adjusting the daily and seasonal changes, and the animals develop specific adaptive periodic activities through rhythm oscillation (Goldman, 2001; Reppert and Weaver, 2002; Tomioka et al., 2012; Partch et al., 2014).

The purpose of this study is comparing the seasonal hormonal changes among selected vertebrates (amphibians, fishes, birds and mammals) in relation to photoperiod in the field.

\section{MATERIALS AND METHODS Study animal}

A license for capturing and sampling was obtained from the Egyptian Environmental Affairs Agency (EEAA).

\section{Experimental animals}

This study was conducted between May 2016 to May 2017. One hundred and four wild animals representing four different vertebrate groups were collected from Damietta governorate. These include 13 males and 13 females of each of the investigated groups of amphibians, fishes, birds, and mammals. Fishes were represented by the African catfish (Clarias garipinus), amphibians were represented by the maculated toad (Bufo regularis), birds were represented by pigeon (Columba livia domesticaes) and mammals were represented by the brown rat (Rattus norvegicus).

\section{Blood sampling}

During four seasons (spring, summer, autumn and winter); the selected species were captured and weighed to the nearest gram. Blood samples were collected from the caudal vein of the African catfish and brown rat, from the heart of the maculated toad, and from the brachial vein of pigeon. Blood samples were collected within 3 minutes maximum to reduce the handling stress, and samples represented no more than $1 \%$ of the body weight (lumeij, 1997). Blood samples were allowed for 30 minutes at room temperature before centrifugation at $1207 \mathrm{xg}$ for 20 minutes. The sera samples then stored at -20 until assayed for selected hormones (estradiol 17$\beta\left(\mathrm{E}_{2}\right)$, testosterone, free thyroxine $\left(\mathrm{FT}_{4}\right)$, and triiodothyronine $\left(\mathrm{FT}_{3}\right)$ later on the same day.

\section{Hormonal assay}

Serum levels of estradiol-17 $\beta \quad\left(\mathrm{E}_{2}\right)$, testosterone, free thyroxine $\left(\mathrm{FT}_{4}\right)$, and triiodothyronine $\left(\mathrm{FT}_{3}\right)$ in both sexes were determined by enzymatic immunoassay ELISA using commercially available kits for a quantitative measurement. Each hormone was read from separate standard curves and each sample was adjusted for percentage recovery of the internal standard. The analysis was run in duplicates.

\section{Statistical analysis}

Values are represented by means \pm SE. The results were analyzed using the XLSTAT program. One-way ANOVA followed by Turkey test was applied to test the significant hormonal differences between classes during seasons. Probability (p) levels of $\leq 0.05$ were considered statistically significant.

\section{Day length:}

\section{RESULTS}

During the sampling period, the longest average day length was $13 \mathrm{~h} 52 \mathrm{~m}$ during spring, while the lowest length was recorded during winter $10 \mathrm{~h} 27 \mathrm{~m}$ (Table 1). 
Table (1). Data of sampling date, seasonal minimum, maximum and mean temperature and seasonal day and night length.

\begin{tabular}{|c|c|c|c|c|c|c|}
\hline Season & $\begin{array}{c}\text { Sampling } \\
\text { date }\end{array}$ & $\begin{array}{c}\text { Minimum } \\
\text { temp }\end{array}$ & $\begin{array}{c}\text { Maximum } \\
\text { temp }\end{array}$ & $\begin{array}{c}\text { Mean } \\
\text { Temp }\end{array}$ & Day length & $\begin{array}{c}\text { Night } \\
\text { length }\end{array}$ \\
\hline Spring & $21 / 5 / 2016$ & 19 & 25 & 24 & $13 \mathrm{~h} 52 \mathrm{~m}$ & $10 \mathrm{~h} 08 \mathrm{~m}$ \\
\hline Summer & $21 / 8 / 2016$ & 25 & 30 & 28 & $13 \mathrm{~h} 07 \mathrm{~m}$ & $10 \mathrm{~h} 54 \mathrm{~m}$ \\
\hline Autumn & $1 / 11 / 2016$ & 20 & 24 & 22 & $10 \mathrm{~h} 55 \mathrm{~m}$ & $13 \mathrm{~h} 05 \mathrm{~m}$ \\
\hline Winter & $21 / 1 / 2017$ & 14 & 18 & 16 & $10 \mathrm{~h} 27 \mathrm{~m}$ & $13 \mathrm{~h} 33 \mathrm{~m}$ \\
\hline
\end{tabular}

Hormonal change:

Free Triiodothyronine $\left(\mathrm{FT}_{3}\right)$ :

Seasonal levels of $\mathrm{FT}_{3}$ in the investigated samples of amphibians, fishes, birds, and mammals are shown in Figure (1). In females, $\mathrm{FT}_{3}$ levels showed significant variations in different classes during summer, autumn and winter $(P \leq 0.01)$, where the highest $\mathrm{FT}_{3}$ concentration was found in amphibians during winter and the lowest one was recorded in mammals during summer (mean $\pm \mathrm{SE}=15 \pm 0.6$ and $2.9 \pm 0.1 \mathrm{ng} / \mathrm{dl}$; respectively, Fig.1a).

On the other hand, $\mathrm{FT}_{3}$ levels in males showed significant variations between different classes in all seasons $(P \leq 0.01)$. The highest concentration was found in amphibians during winter, while mammals showed the lowest concentration during autumn (mean $\pm \mathrm{SE}=17 \pm 0.5$ and $2.30 \pm$ $0.3 \mathrm{ng} / \mathrm{dl}$; respectively, Fig.1b).
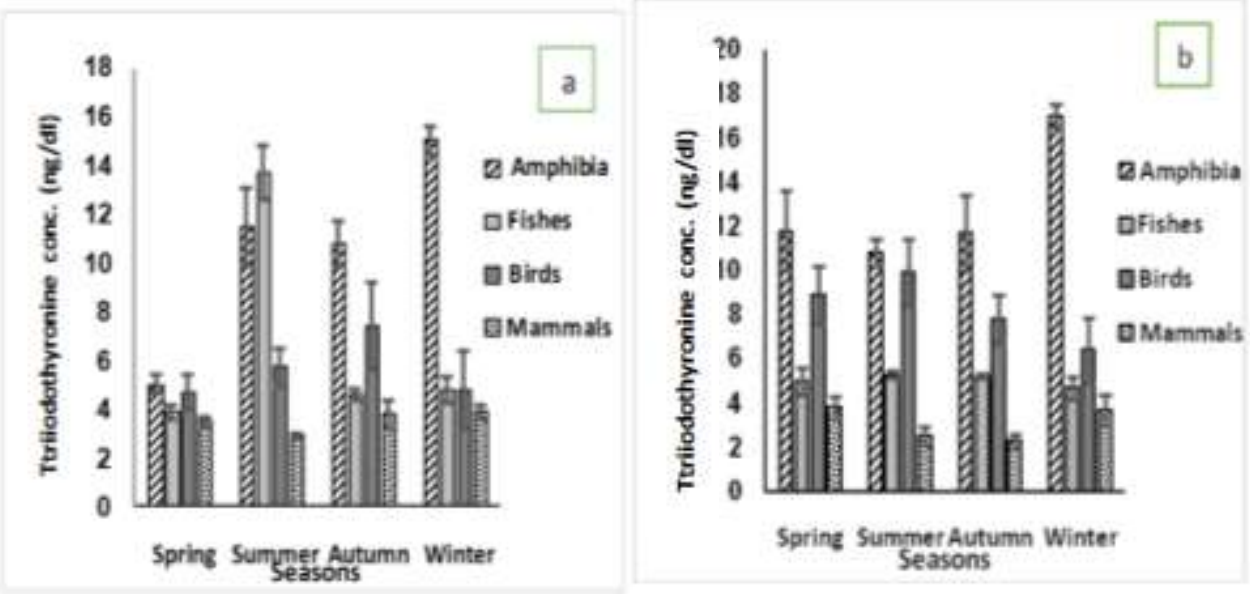

Fig. 1.: Serum concentrations of $\mathrm{FT}_{3}$ (ng/dl) in different classes during different seasons.

(a) In females and (b) In males. Values are represented by means \pm SE

Thyroxine $\left(\mathrm{FT}_{4}\right)$ :

Seasonal levels of $\mathrm{FT}_{4}$ in amphibians, fishes, birds, and mammals are shown in Figure (2). In females $\mathrm{FT}_{4}$ levels showed significant changes between different classes during summer, autumn and winter $(P=0.05, \quad=0.01$ and $=0.002$, respectively). Amphibians showed the mean highest $\mathrm{FT}_{4}$ concentration was recorded during winter and the lowest one was during 
Esraa Ayad et al.

spring $(3.26 \pm 0.3$ and $0.39 \pm 0.1 \mathrm{ng} / \mathrm{dl}$, respectively, Fig. 2a). In relation to males $\mathrm{FT}_{4}$ mean levels showed significant variations between different classes during summer, autumn and winter $(P=0.006$ $=0.05$ and $=0.01$, respectively).

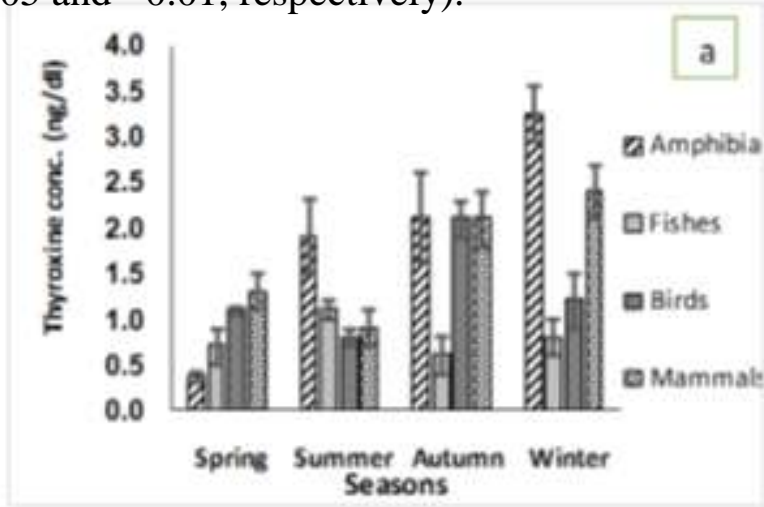

The mean highest $\mathrm{FT}_{4}$ concentration was found in amphibians during winter, while the lowest one was recorded in mammals during summer (2.7 and $0.8 \pm 0.1 \mathrm{ng} / \mathrm{dl}$, respectively, Fig. $2 \mathrm{~b}$ ).

Fig. 2: Serum concentrations of $\mathrm{FT}_{4}$ (ng/dl) in different classes during different seasons. (a) In females and (b) In males. Values are represented by means $\pm \mathrm{SE}$

\section{Estradiol 17- $\beta\left(\mathbf{E}_{2}\right)$ :}

Seasonal mean levels of estradiol 17$\beta\left(\mathrm{E}_{2}\right)$ in amphibians, fishes, birds and mammals are shown in Figure (3). In females $E_{2}$ mean levels showed significant differences between selected animals in all seasons $(P \leq 0.01)$. The highest $\mathrm{E}_{2}$ mean concentration $(315.8 \pm 18.9 \mathrm{pg} / \mathrm{dl})$ was observed in fishes during summer, while the lowest one $(13.1 \pm 4.8 \mathrm{pg} / \mathrm{dl})$ was in

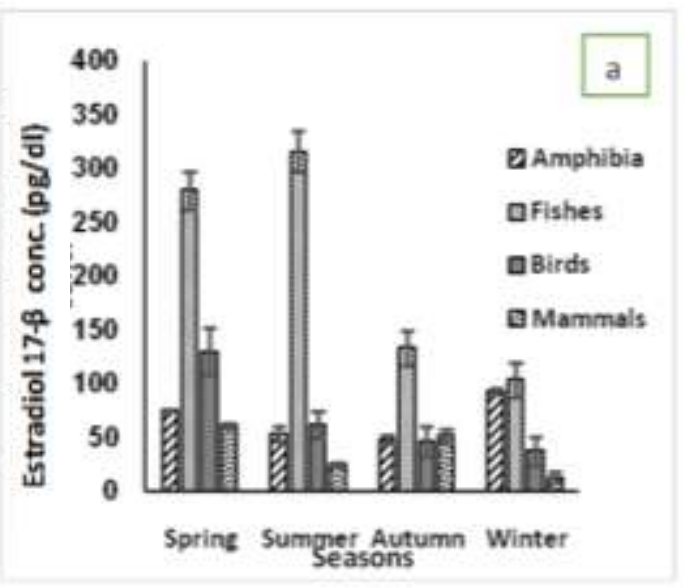

mammals during winter (Fig. 3a). Regarding male $\mathrm{E}_{2}$ mean levels showed significant variations between different classes in all seasons $(P \leq 0.01)$. The highest $\mathrm{E}_{2}$ mean concentration was found in birds during spring, while the lowest one was in amphibians during winter (125.8 \pm 2.6 and $1.2 \pm 0.1 \mathrm{pg} / \mathrm{dl}$, respectively, Fig. $3 b)$.

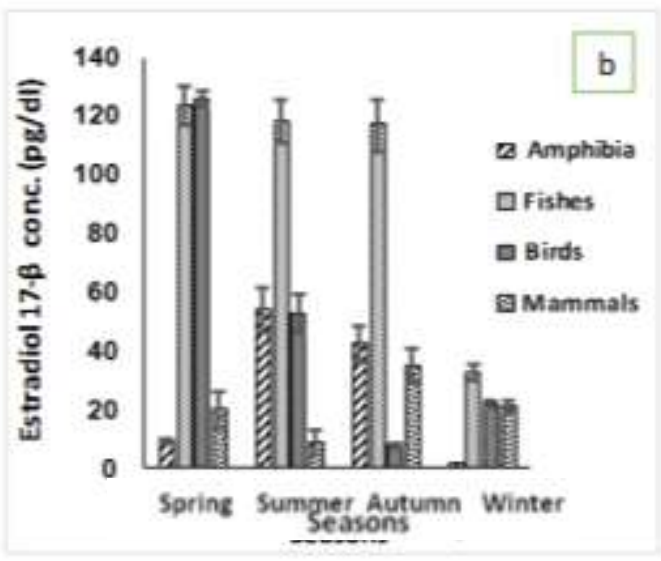

Fig.3: Serum concentrations of estradiol 17- $\beta$ (E2) (pg/dl) in different classes during different seasons. (a) In females and (b) In males. Values are represented by means \pm SE. 
Serum testosterone (T):

Seasonal mean levels of serum testosterone in amphibians, fishes, birds, and mammals are shown in Figure (4). In females testosterone levels showed significant variations between different classes during summer, autumn, and winter $(P \leq 0.02)$. The highest $\mathrm{T}$ mean concentration was found in birds during summer, while the lowest one was in amphibians during summer $\quad(7.30 \pm 1.1$ and $0.2 \pm 0.1 \quad \mathrm{ng} / \mathrm{dl}$; respectively, Fig.4a). For males, testosterone mean levels showed significant differences between different classes during summer, autumn, and winter $(P \leq 0.01)$. The highest testosterone mean concentration was observed in fishes during summer $(8.5 \pm 2.1$ $\mathrm{ng} / \mathrm{dl}$ ), while the lowest one was found in amphibians during summer $(0.5 \pm 0.2 \mathrm{ng} / \mathrm{dl}$ Fig. 4b).
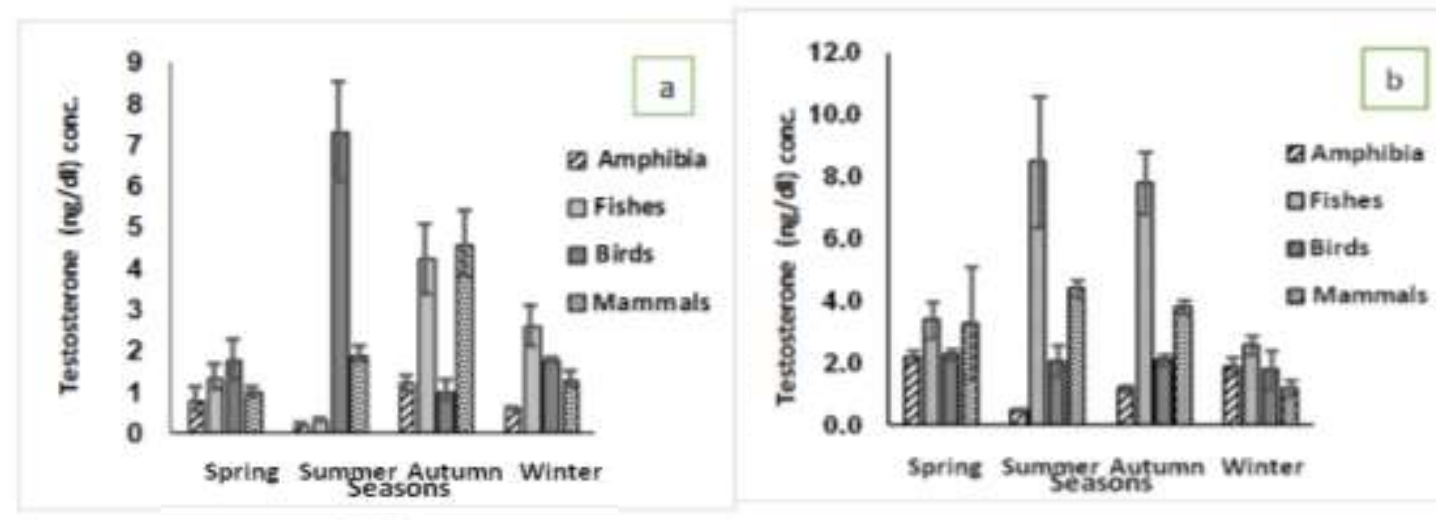

Fig. 4: Serum concentrations of testosterone (ng/dl) in different classes during different seasons. (a) In females and (b) In males. Values are represented by means $\pm \mathrm{SE}$.

\section{DISCUSSION}

The present study aimed to investigate the seasonal changes in thyroid hormones $\left(\mathrm{FT}_{3}\right.$ and $\left.\mathrm{FT}_{4}\right)$ and serum sex steroids (Estradiol 17- $\beta$, testosterone) in representative animals from both sexes of amphibians, fishes, birds, and mammals during spring, summer, autumn, and winter.

$$
\text { Thyroid hormones (THs), }
$$

triiodothyronine $\left(\mathrm{T}_{3}\right)$ and thyroxine $\left(\mathrm{T}_{4}\right)$, play critical roles in the differentiation, growth, metabolism, and physiological function of nearly all mammalian tissues (Yen, 2001; Cheng et al., 2010) In addition, they are required for amphibian metamorphosis (Furlow and Neff, 2006). Multiple biological effects of THs depend on intracellular levels of $\mathrm{T} 3$, which binds to the thyroid hormone receptor and is for the most part generated in peripheral tissues by outer-ring deiodination of $\mathrm{T}_{4}$ (Galton et al., 2009). Thyroid hormones are key metabolic regulators that coordinate shortterm and long-term energy needs (Oetting and Yen, 2007 ). According to the current results, both sexes of amphibians showed the highest concentration of $\mathrm{FT}_{3}$ and $\mathrm{FT}_{4}$ during winter as compared to other classes; this result is in line with Rosenkiled (1982) who found that Bufo bufo has higher plasma $\mathrm{T}_{4}$ during hibernation period and spring than summer and autumn. Similar results by Ceusters et al., (1978) showed that at cold temperatures, iodine uptake by the thyroid 
Esraa Ayad et al.

increases in Rana temporaria. In contrast, another study revealed that $\mathrm{FT}_{3}$ level changed very little throughout the year but $\mathrm{FT}_{4}$ level decreased significantly during hibernating phase (winter). The decreased serum thyroxine in the toad suggests that a state of hypometabolism and decreased metabolic rate would allow further conservation of energy during the crucial phase of hibernation (Suman and Jayanta, 2009). Also, Kuhn et al. (1985) indicated that thyroid content of $\mathrm{T}_{4}$ and $\mathrm{T}_{3}$ was low during winter in Rana ridibunda.

The present study showed that both female and male mammals recorded the lowest concentration of $\mathrm{FT}_{3}$ during summer and autumn, respectively then increased in winter; this finding was in agreement with Thomas and Dora (1996) who found that $\mathrm{FT}_{3}$ concentration was inversely correlated to photoperiod. Cold exposure also increased serum $\mathrm{FT}_{3}$ production, utilization, and metabolic rate. Pallavi et al. (2011) also suggested that $\mathrm{FT}_{3}$ is slightly lower in autumn and slightly higher in winter.

Sex steroids are the regulators of reproductive physiology, sexual differentiation and the development of sexual characteristics (Nelson, 2005). Steroid hormones regulate many physiological processes in vertebrates, including reproduction, growth, and homeostatic mechanisms such as water and energy balance. The roles of steroid hormones in reproduction have been wellstudied in many vertebrates. Sex steroids, in particular are integral regulators of reproductive behaviors and functions across vertebrates. In many species estrogens (estradiol 17- $\beta, \quad \mathrm{E}_{2}$ ) stimulate sexual behavior and vitellogenesis in females, while androgens (testosterone, T) stimulate sexual behavior and spermatogenesis in males (Norris, 1997). Estradiol $17-\beta$ is known to be estrogen steroid hormone that secreted by the cells of the ovarian follicles that promote the development and maintenance of the female sexual characteristics. It plays an important role in the female and male reproductive system. In the current study, the highest concentrations of $E_{2}$ were observed in female fishes during summer which may be due to reaching the breeding season. Pavlidis et al. (2000) recorded high peak in 17 beta-estradiol plasma concentrations associated with the synthesis of vitellogenic proteins (vitellogenin) in many other teleosts. This result coincided with other studies on Acipenser Persicus (Hosseinzade et al., 2012), Rutilus firrsi kutum (Heidari et al., 2018), Labeo rohita (Suresh et al., 2008). In these studies, levels of $E_{2}$ differed during the year and its peak was before spawning.

In the present investigation the highest concentrations of $\mathrm{E}_{2}$ was found in male birds during spring. Similar studies indicated that domestic birds like pigeon bred throughout the year with a peak in spring and summer (Tomasz, 2004) which may explain the high levels of $E_{2}$ in the male birds in the current study. On the other hand, the lowest $\mathrm{E}_{2}$ levels in the current study were observed in female mammals during winter. This result was in line with Gabry et al. (2014) who found that estrogen concentration in adult female rats was significantly higher $(\mathrm{P}<0.05)$ in the long photoperiod group than in the short photoperiod group. The slight differences in hormonal levels between long and short photoperiods may result from a change in the phase of the hormones circadian rhythm rather than a change in their concentration. In contrary, another study revealed that Photoperiod had no effect on estradiol levels in female California mice (Steinman et al., 2011). In relation to males, amphibians recorded the lowest concentrations of $E_{2}$ during winter; this is may be due to the cold temperature and hibernation period. 


\section{Comparison of some metabolic and sex hormones in selected vertebrates in different seasons}

Testosterone is the primary male sex hormone responsible for regulating sex differentiation, producing male sex characteristics, spermatogenesis, and fertility (George and Stephen, 2018). The current results showed that the highest levels of $(\mathrm{T})$ among selected animals were found in female birds during summer. This finding was in line with other studies (Dunmore and Davis , 1963; Murton et al., 1972; Häkkinen et al., 1973; Sengupta, 1974; Dilks, 1975; Johnston, 1984; Dabert, 1987; Johnson and Janiga, 1995) who found that the feral pigeon reproduces in all months of the year, even in winter. Its breeding activity is most intense in the spring and summer and then it decreases markedly in autumn and winter (Janiga and Kocian, 1985) due to deteriorating weather conditions. Skelton et al. (1997) reported high concentrations of testosterone male fishes during summer. In the present work the lowest concentrations of testosterone were observed in both sexes of amphibians during summer. Similar investigations on males of other species indicated that levels of testosterone change during seasons and are coordinated with the spermatogenic cycle (Licht et al., 1985).

\section{REFERENCES}

Argungu, L.A.; Christianus, A.; Amin, M.S.N.; Daud, S.K. and Siraj, S.S. (2015). Annual dynamics of the plasma sex steroid hormones of the Malaysian walking catfish Clarias batrachus (Linnaeus 1758). J. Fish. Aquat. Sci., 10: 24-34.

Bahmani, M.A.; Jourdehi, A.Y.; Kazemi, R.; Pourdehghani, M.; Hallajian, A.; Dejandian, S. and Jalilpour, J. (2009). Seasonal fluctuations of sex steroids (Testosterone, $17 \alpha$-hydroxy progesterone and $17 \quad \beta$-estradiol) with sexual development in farmed Stellate sturgeon, Acipenser stellatus. Iranian Scientific Fish. J., 17(4): 7-16.

Blanton, M.L. and Specker, J.L. (2007). The hypothalamic-pituitary-thyroid (HPT) axis in fish and its role in fish development and reproduction. Critical reviews in toxicology, 37(1-2): 97-115.

Ceusters, R.; Darras, V.M. and Kühn, E.R. (1978). Difference in thyroid function between male and female frogs (Rana temporaria L.) with increasing temperature. General and Comparative Endocrinology, 36(4): 598-603.

Chaurasia, P.; Modi, B.; Mangukiya, S.; Jadav, P. and Shah, R. (2011). Variation in thyroid hormones level among people of different age, gender and seasons, Piparia, Gujarat. Nat. J. Med. Res., 1(2): 5759.

Cheng, S. Y.; Leonard, J.L. and Davis, P.J. (2010). Molecular aspects of thyroid hormone actions. Endocrine reviews, 31(2): 139-170.

Coffin, A.B.; Raine, J.C. and Hawryshyn, C.W. (2012). Exposure to thyroid hormone in ovo affects otolith crystallization in rainbow trout Oncorhynchus mykiss. Environ. Biol. Fishes, 95(3): 347-354.

Dabert, J. (1987). Breeding ecology of the feral pigeon Columba livia $\mathrm{f}$. domestica in Poznań, Poland. Państwowe Wydawnictwo Naukowe at https://www.semanticscholar.org/

Dardente, H.; Hazlerigg, D.G. and Ebling, F.J. (2014). Thyroid hormone and seasonal rhythmicity. Frontiers in Endocrinol., 5: 19.

Dilks, P.J. (1975). The breeding of the feral pigeon (Columba livia) in Hawke's Bay, New Zealand. Notornis, 22(4): 295-301. 
Esraa Ayad et al.

Dunmore, R. and Davis, D.E. (1963). Reproductive condition of feral pigeons in winter. The Auk, 80(3): 374-374.

Eales, J.G. and Brown, S.B. (1993). Measurement and regulation of thyroidal status in teleost fish. Reviews in Fish Biology and Fisheries, 3(4): 299-347.

Feder, M. E. and Burggren, W.W. (1992). Environmental physiology of the amphibians. University of Chicago Press.

Furlow, J.D. and Neff, E.S. (2006). A developmental switch induced by thyroid hormone: Xenopus laevis metamorphosis. Trends in Endocrinology \& Metabolism, 17(2): 40-47.

Gabry, M.S.; El-Hennamy, R.E.; Ibrahim, M.A. and Fathalla, A.S. (2014). The role of different photoperiods in the activation of the thyroid gland and ovaries of adult and aged rats (Rattus norvegicus). Egypt. J. Hospital Med., 31(1587): 1-24.

Galton, V.A.; Schneider, M.J.; Clark, A.S. and St. Germain, D.L. (2009). Life without thyroxine to $3,5,3$ 'triiodothyronine conversion: studies in mice devoid of the 5'deiodinases. Endocrinology, 150(6): 2957-2963.

Goldman, B.D. (2001). Mammalian photoperiodic system: formal properties and neuroendocrine mechanisms of 293 photoperiodic time measurement. J. Biol. Rhythms 16: 283-301.

Häkkinen, I.; Jokinen, M. and Tast, J. (1973). The winter breeding of the feral pigeon Columba livia domestica at Tampere in 1972/1973. Ornis Fennica, 50:83-88.

Heidari, B.; Roozati, S.A.A. and Yavari, L. (2018). Changes in plasma levels of steroid hormones during oocyte development of Caspian kutum (Rutilus frisii kutum). Anim. Reprod., 7: 373-381.

Hetmański, T. (2004). Timing of breeding in the Feral Pigeon Columba livia f. domestica in Słupsk (NW Poland). Acta Ornithologica, 39(2), 105-110.

Hosseinzade, M., M. R. Imanpoor, and S. M. Aghilinejhad. (2012)."Changes in Serum Steroid Hormones by Ovarian Development of Persian Sturgeon (Acipenser Persicus) during Final Maturation Induced by Hormonal Treatment. 1: 532 doi: 10.4172/scientificreports. 532 Page 2 of 4 Volume $1 \bullet$ Issue $11 \bullet$

Janiga, M. and Kocian, L. (1985). Some aspects of the nidobiology of the pigeon (Columba livia f. domestica) in Bratislava. Folia zoologica, 34(2):133-147.

Klaren, P.H.; Guzmán, J.M.; Mancera, J.M.; Geven, E.J. and Flik, G. (2005). The involvement of thyroid hormone metabolism in gilthead sea bream (Sparus auratus) osmoregulation. Annals of the New York Academy of Sciences, 1040(1): 360-362.

Kousha, A.; Askarian, F.; Yousefian, M.; Ghate, H.V. and Ghole, V.S. (2009). Annual Fluctuation of Sex Steroid Hormones in Pre-spawning Female Kutum (Rutilus frissi kutum). World J. Fish and Mar. Sci.,1: 65-73.

Kühn, E.R.; Darras, V.M. and Verlinden, T.M. (1985). Annual variations of thyroid reactivity following thyrotropin stimulation and circulating levels of thyroid hormones in the frog Rana ridibunda. General and Comparative Endocrinol., 57(2): 266-273. 
Lema, S.C. and Nevitt, G.A. (2004). Evidence that thyroid hormone induces olfactory cellular proliferation in salmon during a sensitive period for imprinting. J. Exper. Biol., 207(19): 3317-3327.

Licht, P.; Breitenbach, G.L. and Congdon, J.D. (1985). Seasonal cycles in testicular activity, gonadotropin, and thyroxine in the painted turtle, Chrysemys picta, under natural conditions. General and Comparative Endocrinol., 59(1):130-139

Matsuyama, M.; Adachi, S.; Nagahama, Y.; Kitajima, C. and Matsuura, S. (1991). Annual reproductive cycle of the captive female Japanese sardine Sardinops melanostictus: Relationship to ovarian development and serum levels of gonadal steroid hormones. Mar. Biol., 108(1): 21-29.

Morton, M.L.; Orejuela, J.E. and Budd, S.M. (1972). The biology of immature mountain white-crowned sparrows (Zonotrichia leucophrys oriantha) on the breeding ground. The Condor, 74(4): 423-430.

Nelson, E.R.; Allan, E.R.; Pang, F.Y. and Habibi, H.R. (2010). Thyroid hormone and reproduction: regulation of estrogen receptors in goldfish gonads. Molecular reproduction and development, 77(9): 784-794.

Nelson, R.J.; Denlinger, D.L. and Somers, D.E. (2010). Photoperiodism: the biological calendar. Oxford University Press.

Norris, D.O. and Deviche, P. (1997). Vertebrate Endocrinology. General and Comp. Endocrinology, 108(2): 340-340.

Oetting, A. and Yen, P.M. (2007). New insights into thyroid hormone action. Best Pract. Res. Clin. Endocrinol. Metab., 21:193-208.
Partch, C.L.; Green, C.B. and Takahashi, J.S. (2014). Molecular architecture of the mammalian circadian clock. Trends Cell Biol., 24: 90-99.

Pavlidis, M.; Greenwood, L.; Mourot, B.; Kokkari, C.; Le Menn, F.; Divanach, P. and Scott, A.P. (2000). Seasonal variations and maturity stages in relation to differences in serum levels of gonadal steroids, vitellogenin, and thyroid hormones in the common dentex (Dentex dentex). General and Comparative Endocrinol., 118(1): 14-25.

Peter, M.S. (2011). The role of thyroid hormones in stress response of fish. General and Comp. Endocrinol., 172(2): 198-210.

Pratihar, S. and Kundu, J.K., (2009). Increased serum magnesium and calcium and their regulation during hibernation in the Indian Common Toad, Duttaphrynus melanostictus (Schneider, 1799). South Amer. J. Herpetol., 4(1): 51-55.

Pratihar, S. and Kundu, J. K. (2009). Metabolic changes during hibernating period in Indian common toad, Duttaphrynus melanostictus (Schneider, 1799). J. Appl. and Nat. Sci., 1(1), 44-46.

Reppert, S.M. and Weaver, D.R. (2002). Coordination of circadian timing in mammals. Nature 418: 935-941.

Rosenkilde, P. (1982). The role of thyroid hormone in adult amphibians. In: Phylogenic Aspects of Thyroid Hormone Actions, (Institute of Endocrinology Gunma University, ed.), pp. 91-106. Center for Academic Publications Japan, Tokyo.

Rosenkilde, P. and Jorgensen, I. (1977). Determination of serum thyroxine in two species of toads: Variation with 


\section{Esraa Ayad et al.}

season. Gen. Camp. Endocrinology, 33: 566-573.

Schreiber, A.M. and Specker, J.L. (1998). Metamorphosis in the summer flounder (Paralichthys dentatus): stage-specific developmental response to altered thyroid status. General and comparative Endocrinol., 111(2): 156-166.

Sehafii, H.H.; Khodadadi, M. and Behbahani, S.A. (2014). Seasonal Fluctuations of Sex Steroid Hormones in Indian Major Carp Catla catla in Khouzestan, Iran. J. Environ. \& Analy. Toxicol., 4(5): 1.

Shiao, J. C. and Hwang, P. P. (2006). Thyroid hormones are necessary for the metamorphosis of tarpon Megalops cyprinoides leptocephali. J. Exper. Mar. Biol. Ecol., 331(2): 121-132.

Skelton, P. (1993). A Complete Guide to the Freshwater Fishes of Southern Africa. Halfway House: Southern Book Publishers Ltd.

Steinman, M.Q.; Crean, K.K. and Trainor, B.C. (2011). Photoperiod interacts with food restriction in performance in the Barnes maze in female
California mice. European J. Neurosci., 33(2): 361-370.

Suresh, D.; Baile, V.V. and Rao, P. P. (2008). Annual reproductive phaserelated profile of sex steroids and their carrier, SHBG, in the Indian major carp, Labeo rohita. General and Comp. Endocrinol., 159(2-3): 143-149.

Tomasi, T.E. and Mitchell, D.A. (1996). Temperature and photoperiod effects on thyroid function and metabolism in cotton rats (Sigmodon hispidus). Comparative Biochemistry and Physiology Part A: Physiology, 113(3): 267-274.

Tomioka, K.; Uryu, O.; Kamae, Y.; Umezaki, Y. and Yoshii, T. (2012). Peripheral circadian rhythms and their regulatory mechanism in insects and some other arthropods: a review. J. Comp. Physiol., B 182: 729-740.

Yen, P. M. (2001). Physiological and molecular basis of thyroid hormone action. Physiological reviews, 81(3): 1097-1142. 